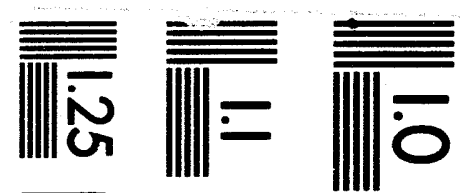

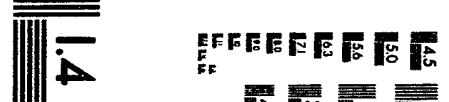

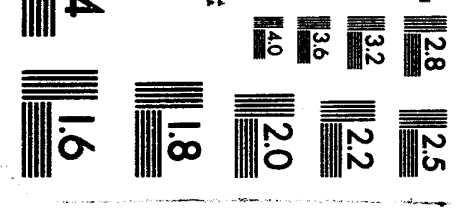



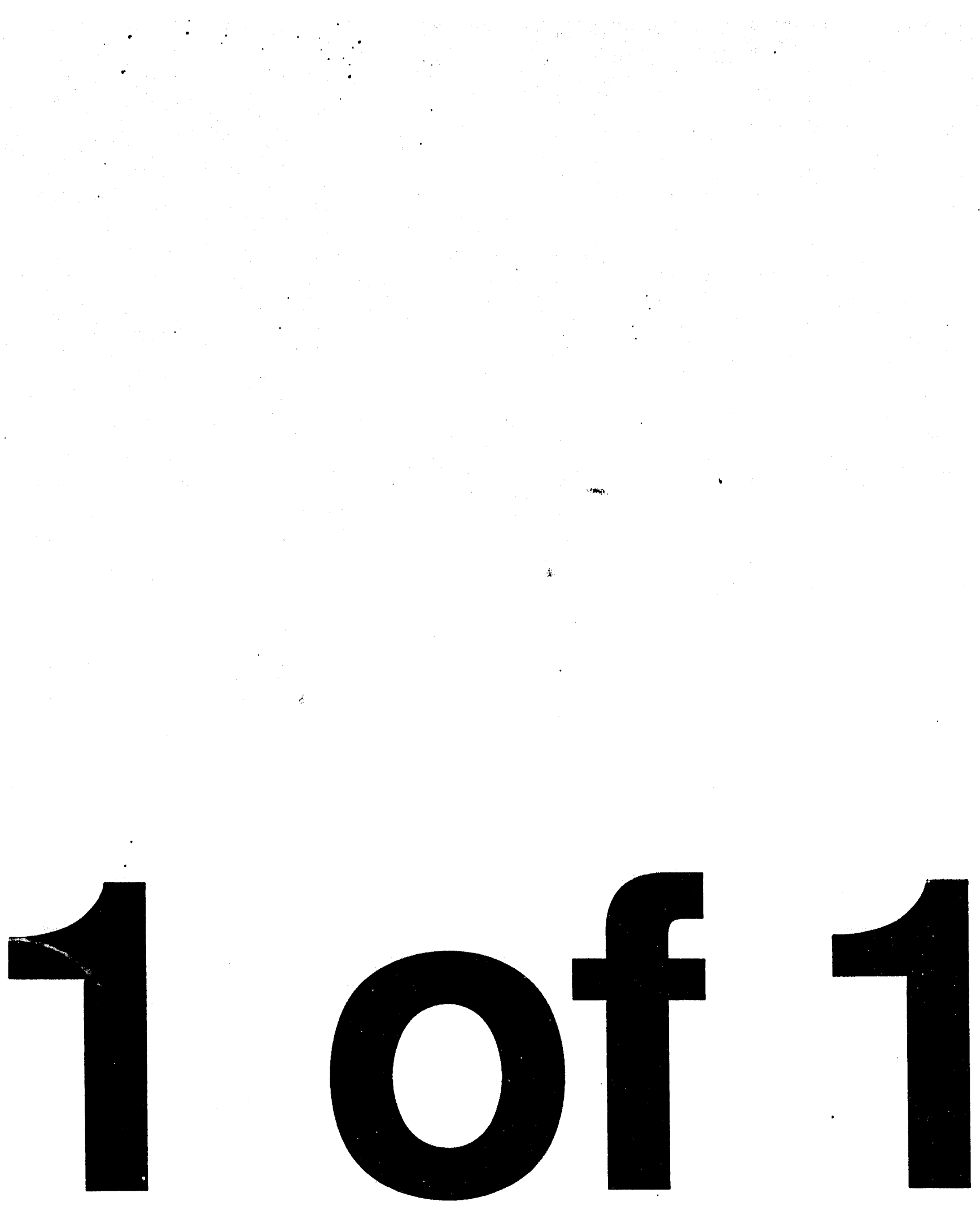


\title{
Application of Intrinsic Germanium Spectral Gamma-Ray Logging for Characterization of High-Level Nuclear Waste Tank Leaks
}

\author{
J. R. Brodeur \\ J. P. Kiesler \\ S. E. Kos \\ C. J. Koizumi \\ W. F. Nicaise \\ R. K. Price
}

Date Published

November 1993

Prepared for the U.S. Department of Energy

Office of Environmental Restoration and

Waste Management

\section{(2) Westinghouse

Copyright License By acceptance of this article, the publisher and/or recipient acknowledges the U.S. Government's right to Copyright License By acceptance of this article, the publisher and/or recipient ack
tetain a nonexclusive, royalty-tree license in and to any copyright covering this paper. 


\section{LEGAL DISCLAIMER}

This report was prepared as an account of work sponsored by an agency of the United States Government. Neither the United States Government nor any agency thereof, nor any of their employees, nor any of their contractors, subcontractors or their employees, makes any warranty, express or implied, or assumes any legal liability or responsibility for the accuracy, completeness, or any third party's use of the results of such use of any information, apparatus, product, or process disclosed, or represents that its use would not infringe privately owned rights. Reference herein to any specific commercial product, process, or service by trade name, trademark, manuiacturer, or otherwise, does not necessarily constitute or imply its endorsement, recommendation, or favoring by the United States Government or any agency thereol or its contractors or subcontractors. The views and opinions of authors expressed herein do not necessarily state or reflect those of the United States Government or any agency thereof.

This report has been reproduced from the best available copy.

Printed in the Uniled States of Ameriea

OISCLIN-2.CHP (1-91) 


\title{
APPLICATION OF INTRINSIC GERMANIUM SPECTRAL GAMMA-RAY LOGGING FOR CHARACTERIZATION OF HIGH-LEVEL NUCLEAR WASTE TANK LEAKS
}

\author{
By J. R. Brodeur, J. P. Kiesler, C. J. Koizumi, \\ S. E. Kos, W. F. Nicaise, and R. K. Price
}

\begin{abstract}
Spectral gamma-ray logging with a high-resolution, intrinsic germanium logging systert was completed in boreholes surrounding two high-level nuclear waste tanks at the U.S. Department of Energy's Hanford Site. The purpose was to characterize the concentrations of man-made radionuclides in the unsaturated zone sediments and identify any new leaks from the tanks.

An intrinsic germanium detection system was used for this work because it was important to positively identify the specific radionuclides and to precisely assay those radionuclides.

The spectral gamma log data were processed and displayed as log plots for each individual borehole and as three-dimensional plots of ${ }^{137} \mathrm{Cs}$ radionuclide concentrations. These data were reviewed to identify the sources of the contamination.

The investigation did not uncover a new or active leak from either of the tanks. Most of the contamination found could be related to known pipeline leaks, to surface contamination from aboveground liquid spills, or to leaks from other tanks. The current spectral gamma ray data now provide a new baseline from which to compare future log data and identify any changes in the radioelement concentration.

\section{INTRODUCTION}

\section{Background}

From the early 1940's to the late 1980's, fissionable plutonium and uranium were produced at processing facilities at the U.S. Department of Energy's Hanford Site in southeastern Washington State (Figure 1). These processing facilities extracted specific isotopes from fuel rods that were irradiated in one of several reactors operated on the Hanford Site.

Various chemical extraction processes generated millions of gallons of high-level nuclear waste effluent. This effluent was placed in storage in 177 underground storage tanks; 149 tanks were constructed from the early 1940's to mid-1960's with a single carbon-steel-lined concrete shell and are called single-shell tanks (SST); 28 additional tanks were built from the late 1960's to mid 1980's with doublesteel-lined concrete shells (double-shell tanks [DST]). A schematic of a SST is shown in Figure 2.

Proper management of the waste tanks requires monitoring, so various types of instruments are

installed in and around the tanks to measure liquid levels, temperatures, solid levels, and in-tank humidity. One objective of the monitoring program is to detect leaks from the SST.

The SST were designed as "temporary" storage to alleviate an immediate waste problem and keep nuclear materials production facilities operating. Some of these tanks began leaking shortly after receiving waste and others developed leaks after being exposed to high temperatures and corrosive salt-laden liquids over time.

Currently, 67 of the 149 SST are classified as known leakers. If a tank is known to leak, the liquid remaining in the tank is promptly pumped to a DST.

The primary method of detecting leaks from the tanks is with in-tank liquid-level sensors. However, not all tanks have sensors, and liquid-level measurements are not always reliable, especially when there is a significant amount of salt sludge or solids in the tank. Also, heat generated by the contents of some tanks causes evaporation, which makes it difficult to distinguish evaporation level decreases from tank leaks.
\end{abstract}




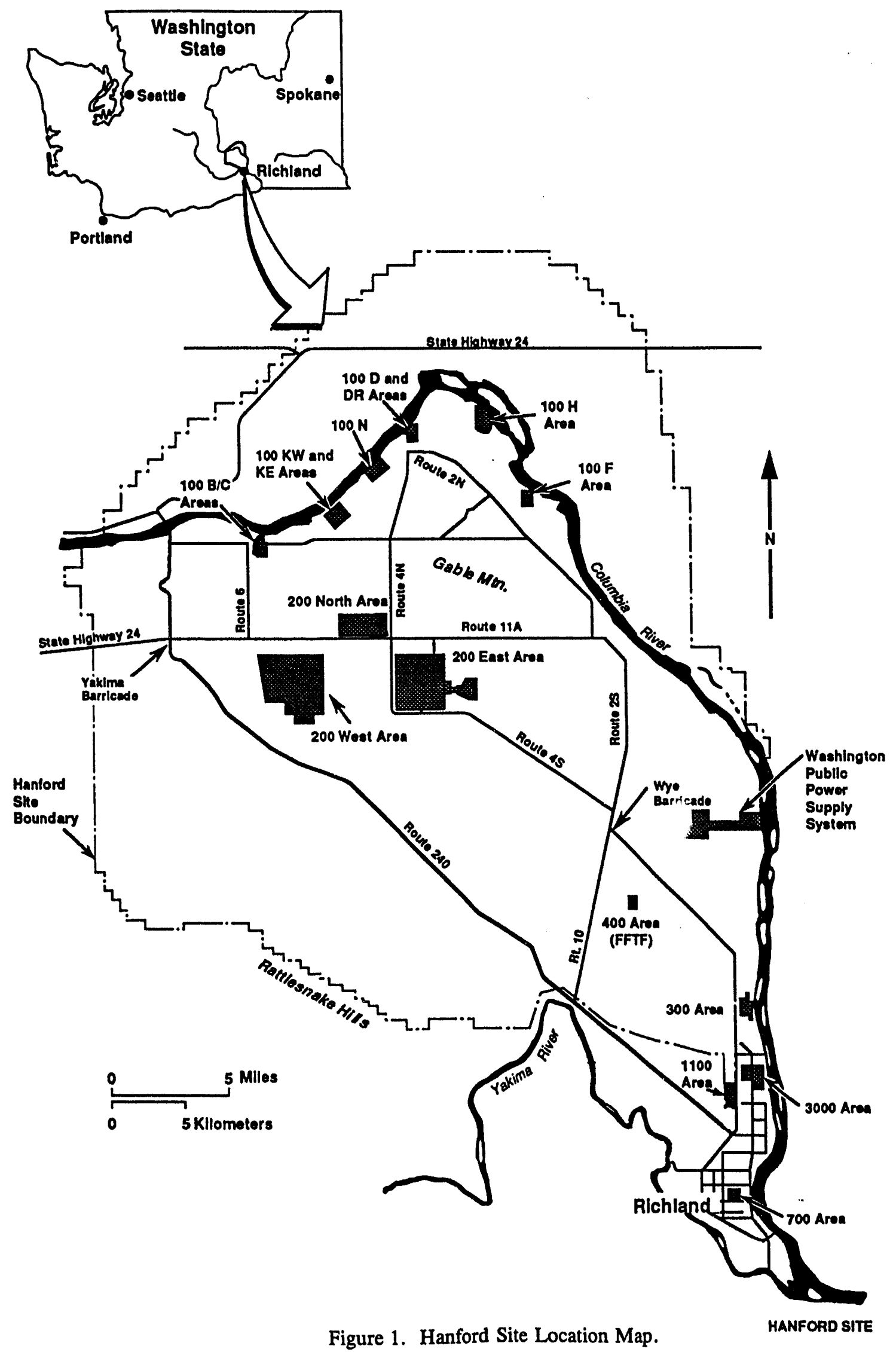


WHC-SA-2172-FP

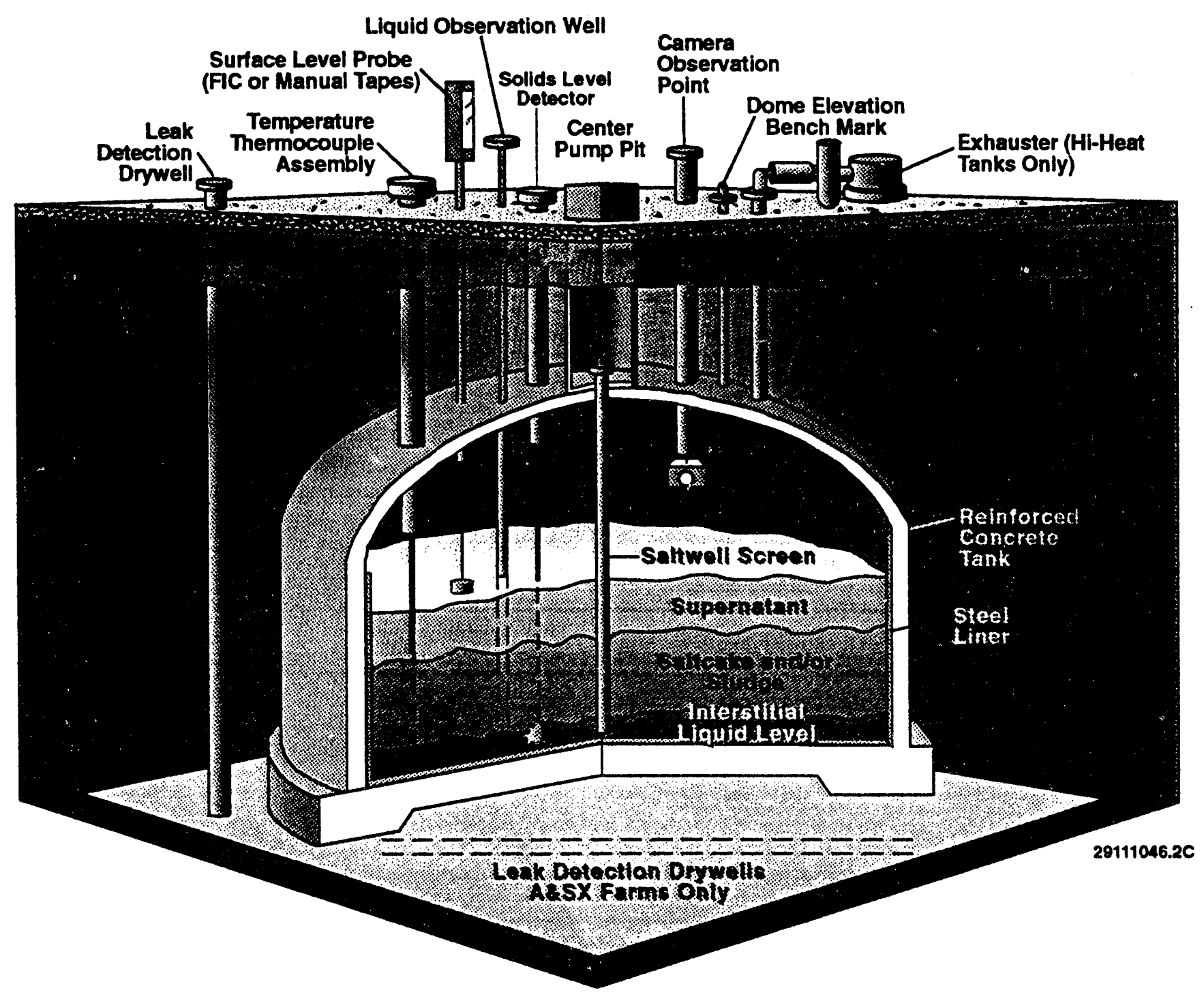

Figure 2. Schematic of a Single-Shell Tank. 


\section{WHC-SA-2172-FP}

To assist in leak detection, boreholes were drilled around most of the SST to provide access for borehole geophysical monitoring equipment.

In the late 1970's, a gross gamma logging program was started to monitor the unsaturated zone and help detect leaks from the tanks. When radionuclide-laden liquid comes in close proximity to a monitoring borehole, an increase in the gamma flux is seen in the log thereby alerting a log analyst to a problem.

Recently, an intrinsic germanium spectral gamma-ray logging system was developed for use at the Hanford Site allowing more sensitive monitoring and better characterization. This paper describes the first attempt at a comprehensive characterization of the unsaturated zone around two of the high-level waste tanks.

In this paper, a "gross gamma" log refers to data generated from a sodium iodide-based gross gamma detection system, while a "total gamma" log refers to the data generated by summing the total number of gamma ray photons detected in each spectrum from the intrinsic germanium-based detection system.

The two SST that were studied are called the C-105 and C-106 tanks. They are located in the C tank farm, a collection of 12 tanks buried so the tops of their domes are about $7 \mathrm{ft}$ below the surface. These tanks each have 530,000-gal capacities, are $75 \mathrm{ft}$ in diameter, and are $23 \mathrm{ft}$ high. A schematic of the tank farm is provided in Figure 3.

Tanks C-105 and C-106 are unique in C tank farm because they received high quantities of heatgenerating ${ }^{90} \mathrm{Sr}$. Water was added to the tanks at regular intervals to cool the waste and prevent damage to the tank walls. The liquid level in the tanks increased when water was added, then slowly decreased. Those decreases were attributed to evaporation, but the possibility of a leak from either tank could not be ruled out, based solely on liquid level data.

Gross gamma log data did not show that a leak was occurring. However, because the spectral gamma equipment provides at least an order of magnitude greater sensitivity over the gross gamma system, it was decided to use the spectral system to evaluate the unsaturated zone radionuclide contamination.

\section{Purpose}

The purpose of the logging operation was to determine if there was any indication of recent leaks from either of these tanks. This was accomplished by characterizing the radionuclide distribution around the tanks and identifying the sources of the existing contamination.

Numerous surface transfer line spills and subsurface pipeline leaks have occurred in the tank farm making it difficult to differentiate the spills and pipeline leaks from actual tank leaks.

It was also intended to baseline the existing contamination to allow future comparisons, thus identifying any changes in the radionuclide concentration, which can indicate an active tank leak.

Identifyirg a dynamic unsaturated zone radionuclide transport system is the key to identifying a tank leak.

\section{HISTORICAL DATA}

An extensive library of gross gamma logs was available from which to determine the approximate location and relative intensity of the gamma ray flux in the boreholes. These data were recorded from the late 1970's to the present. Much of this data were available in paper copy as opposed to digital records, but the data were still useful for identifying contamination zones and determining when the contamination first appeared. Many gross gamma records were collected and reviewed for this study.

Geology and hydrology data were also available. This included borehole lithology logs, geologic cross sections, regional geology information, groundwater chemistry, radionuclide assay data, and groundwater flow information. These data were collected and reviewed as part of the study.

A large library of tank infermation was reviewed, including internal memos, tank contents information, unusual occurrence reports, and various other reports generated over 30 years of tank operations.

Unfortunately, some critical information about the tanks is not available. These critical data include information about surface spills and pipeline leaks, or older tank monitoring data. 


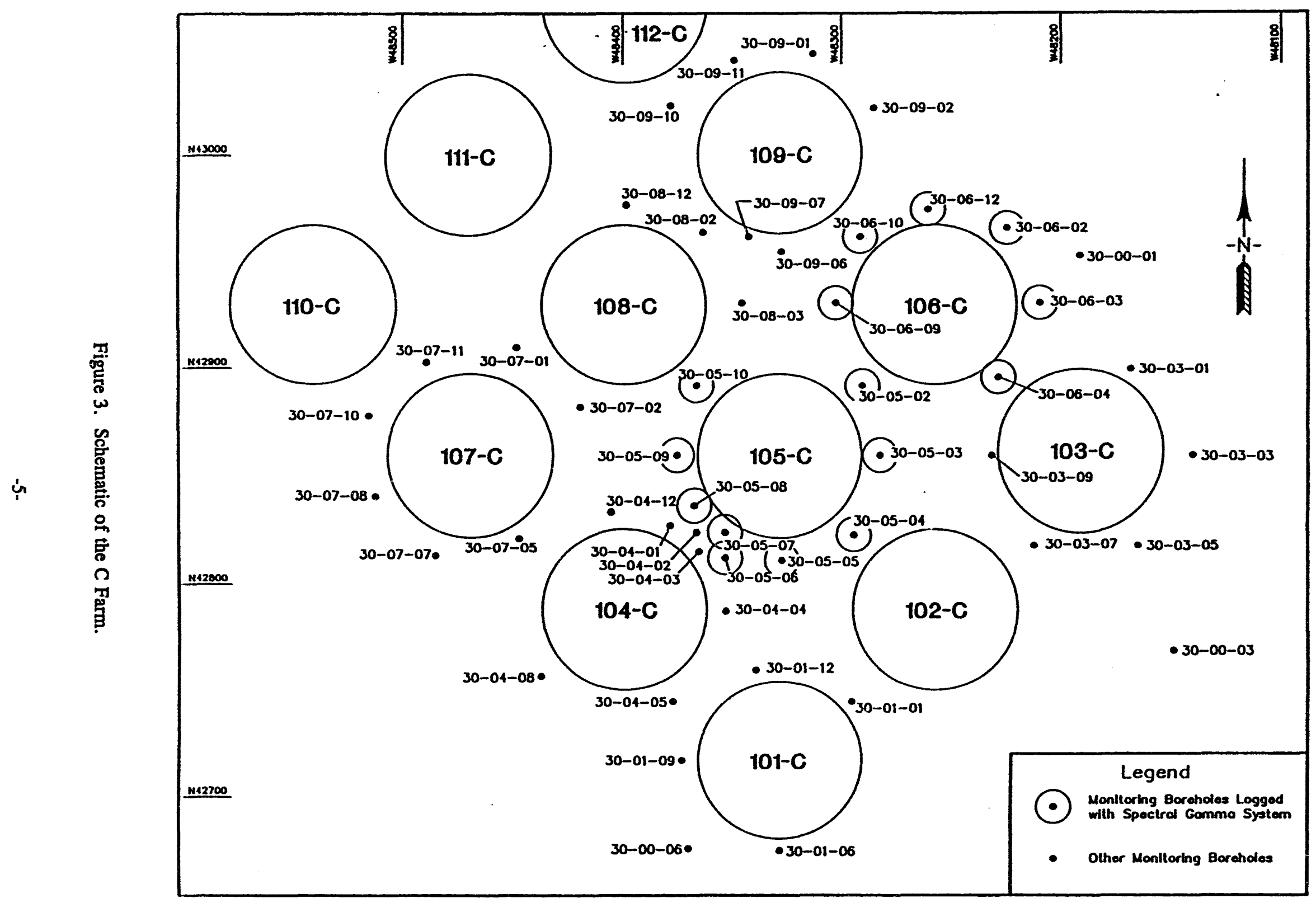


Some more detailed information is contained in shift reports and daily logs which are not routinely included in the regular tank information files and are difficult to access. However, many spills or occurrences were simply not investigated and documented. As a result, little information is available on surface spills, pipeline leaks, or tank vapor emissions.

The information that was available was collected and reviewed in preparation for interpreting the log data and identifying sources of the contamination in the unsaturated zone.

\section{SPECTRAL GAMMA LOG MEASUREMENTS}

\section{Equipment}

The spectral gamma logging system utilizes an intrinsic germanium detector to provide high-energy resolution spectra. High resolution is required because it is difficult to separate, uniquely identify, and assay the individual gamma rays from the man-made radionuclides with a conventional sodium iodide-based spectral gamma-ray logging system. The man-made radionuclide peaks are often obscured by the peaks from naturally occurring radionuclides, especially when the man-made radionuclides are found at low concentrations in the sediment surrounding the boreholes. Figure 4 shows a comparison of the germanium and sodium iodidederived spectra.

The logging system has a detector with an efficiency of $18 \%$ relative to a standard 3 -inch by 3 -inch sodium iodide detector. It is mounted in the downhole probe along with the necessary high-voltage power supply, the preamplifiers, and a cryogenic system required to maintain the detector at liquid nitrogen temperatures.

The surface electronics consist of laboratory quality, gamma-ray spectroscopy amplifiers and counting equipment interfaced to a high-end personal computer. The surface equipment is mounted in a conventional logging truck, which contains a computer-controlled hydraulic winch system that controls the position and movement of the downhole probe in the borehole. The system is automated and all data acquisition is under computer control.

A complete description of the logging system is provided in Koizumi et al. (1994).
The equipment is calibrated yearly to radioelement specific, in situ radionuclide concentrations using a calibration method specifically devised for assay of man-made radionuclides. The calibration is described in Brodeur et al. (1991).

\section{Logging Operations}

Spectral gamma logging was completed in 15 boreholes surrounding tanks C-105 and C-106 as shown in Figure 3. Data acquisition operations were governed by a logging procedure that is general enough to permit variations in critical factors of the logging operation such as counting time, data acquisition interval and logging modes according to the data needs of a particular project. However, the procedure requires that such parameters be recorded on separate log data sheets prepared for each log run. In this manner, the data acquisition operation follows a procedure to generate repeatable, quality assured data while still permitting flexibility in the logging operations.

For this project, spectra were recorded along the entire length of each borehole with the system operated in a move-stop-acquire mode. The distance between spectrum recordings in the borehole was $0.5 \mathrm{ft}$ and each spectrum was recorded with a counting time of 80 seconds. An 80 -second counting time was adequate for assay of the intense, man-made radionuclides down to a concentration of about $1 \mathrm{pCi} / \mathrm{g}$. However, it was not quite long enough to generate good statistics for the low count rate, natural gamma emitters, ${ }^{40} \mathrm{~K},{ }^{238} \mathrm{U}$ and ${ }^{232} \mathrm{Th}$. Longer spectrum counting times provide lower counting uncertainty for the individual gamma ray peaks, but if a longer counting time were used it would not have been possible to log one borehole per day. A stationary, 300-second spectrum was also recorded at the bottom of some of the boreholes.

The ground surface of the tank farm is contaminated with radioactive material, so the logging truck was kept outside the tank farm during logging operations. The logging cable was suspended from the truck to a portable sheave wheel mounted over the boreholes. Nuclear operators in protective clothing handled the logging tool and cable inside the tank farm. The operators were on supplied air whenever they were in the tank farm because of potential release of harmful organic vapor from one of the tanks in the tank farm. These special health and safety precautions complicated the logging job considerably. 


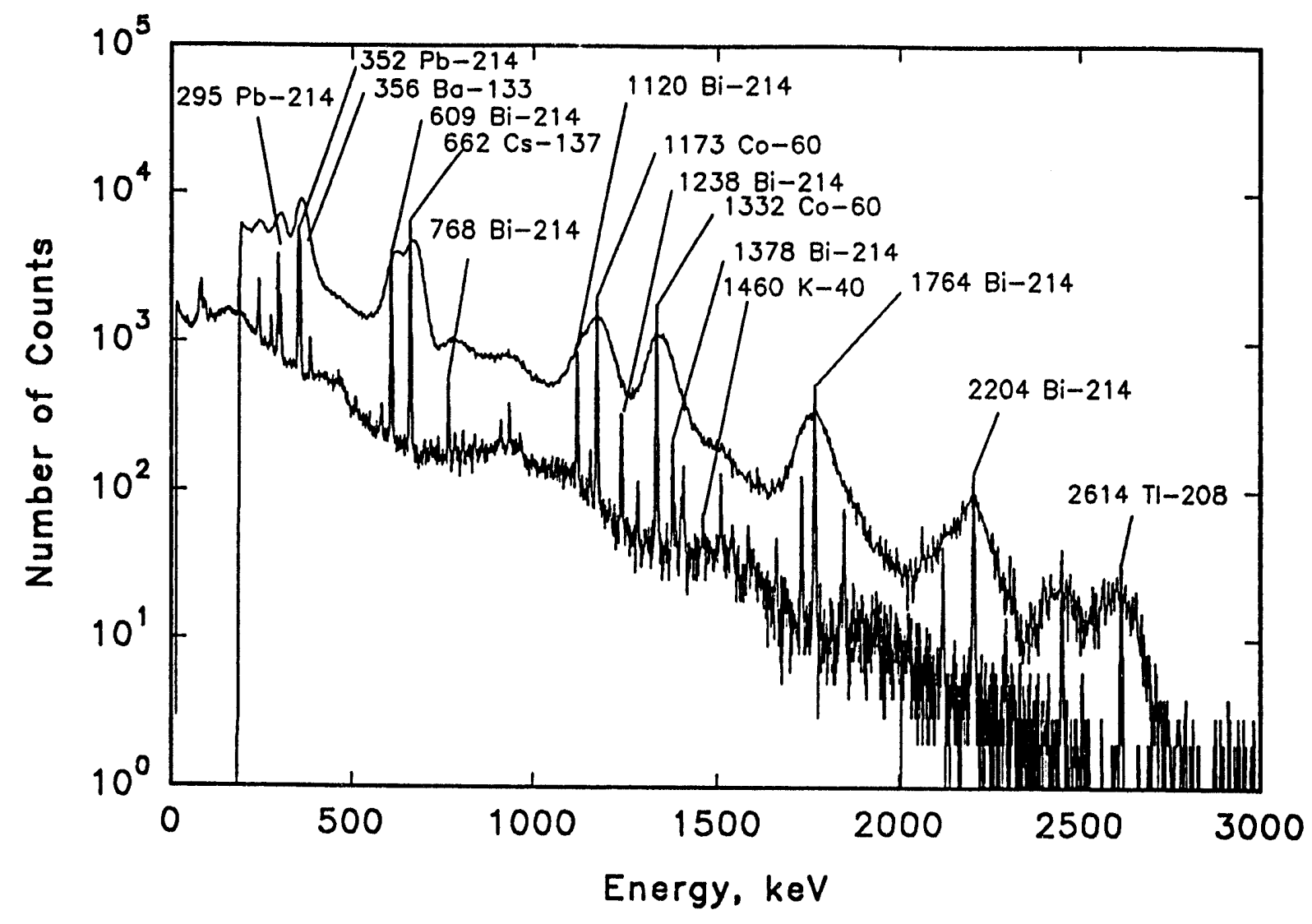

Figure 4. Comparison of the NaI and HpGe Energy Resolution.

Spectra data were recorded on disk in the field and transferred to a computer system for analysis with custom software written specifically for analyzing the borehole spectra. The software identified the gamma-ray peaks, determined the count rate of individual peaks, and converted the count rate data to in situ radio-element concentration using the latest calibration data. Any appropriate borehole environmental corrections (such as casing corrections) were applied to the concentration data. Finally, the data were tabulated as specific isotope concentration versus depth and log displays were prepared.

\section{DISCUSSION}

\section{Spectral Log Review}

This type of work had never been done on Hanford Site tanks so a considerable amount of time was spent determining exactly what types of correlations could be made, what kind of analyses were applicable, and how to present the data. Finally, the data were presented in two ways. The data from each borehole were plotted separately as man-made and natural radionuclide concentrations such as those shown in Figures 5 and 6 . This permitted correlation of different data from the same borehole.

The plots allow visualization of the type and distribution of man-made radionuclides around the tanks. They allow comparison of the man-made contamination type and distribution to borehole lithology as determined from the drill logs and from the potassium, uranium, and thorium logs. The man-made radionuclide concentration logs were also correlated with the gross gamma logs to determine how the gross gamma historical record related to the current contamination profile.

The second method of data presentation was to prepare three-dimensional plots of the cesium concentration and the gross gamma count rates.

Cesium-137 was the most abundant man-made contaminant in the unsaturated zone. These concentration data were put into a three-dimensional visualization program to better understand the cross borehole contamination distribution. An example of a 


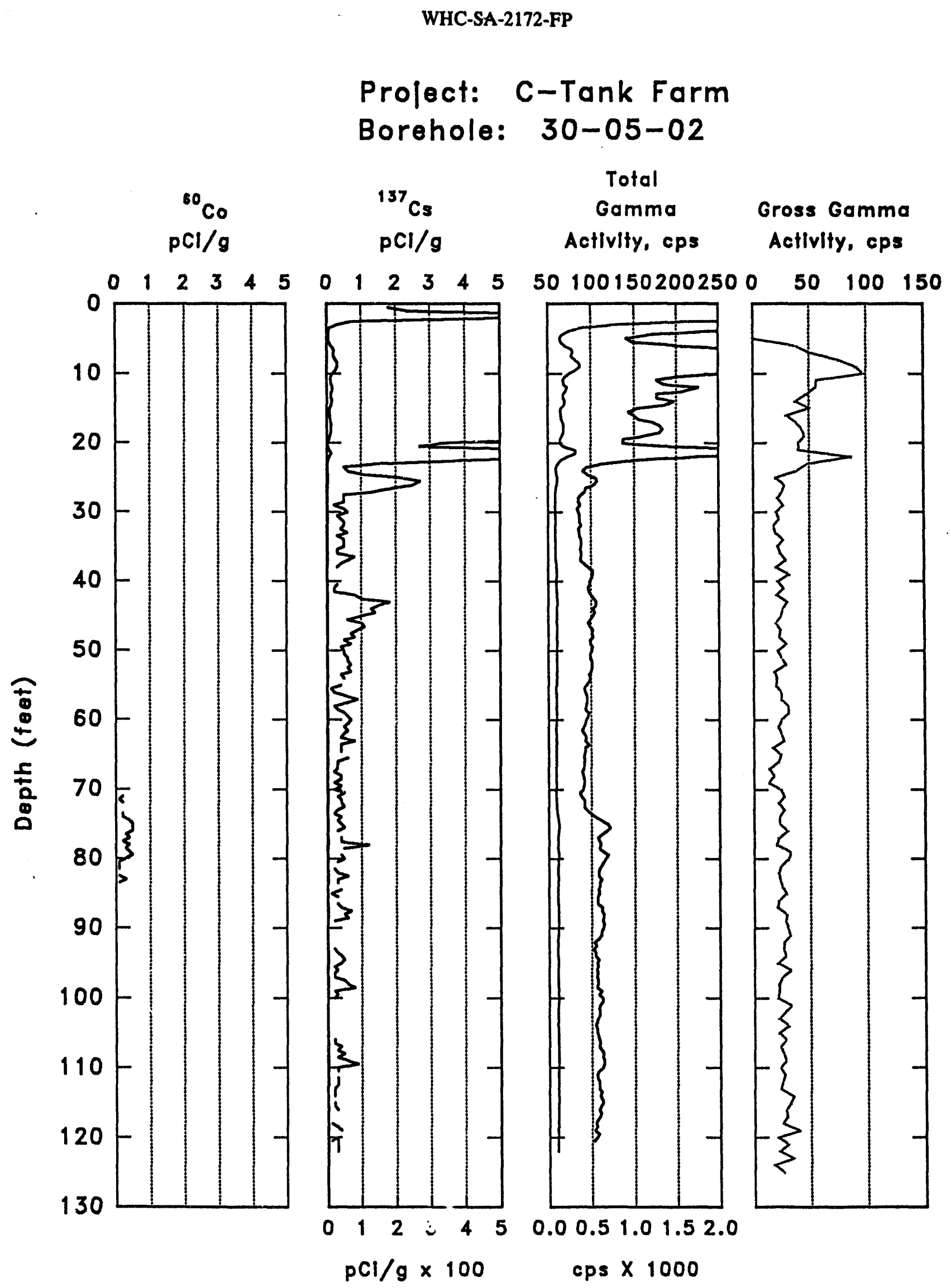

Figure 5. Spectral Gamma Logs of Man-Made Radionuclides. 


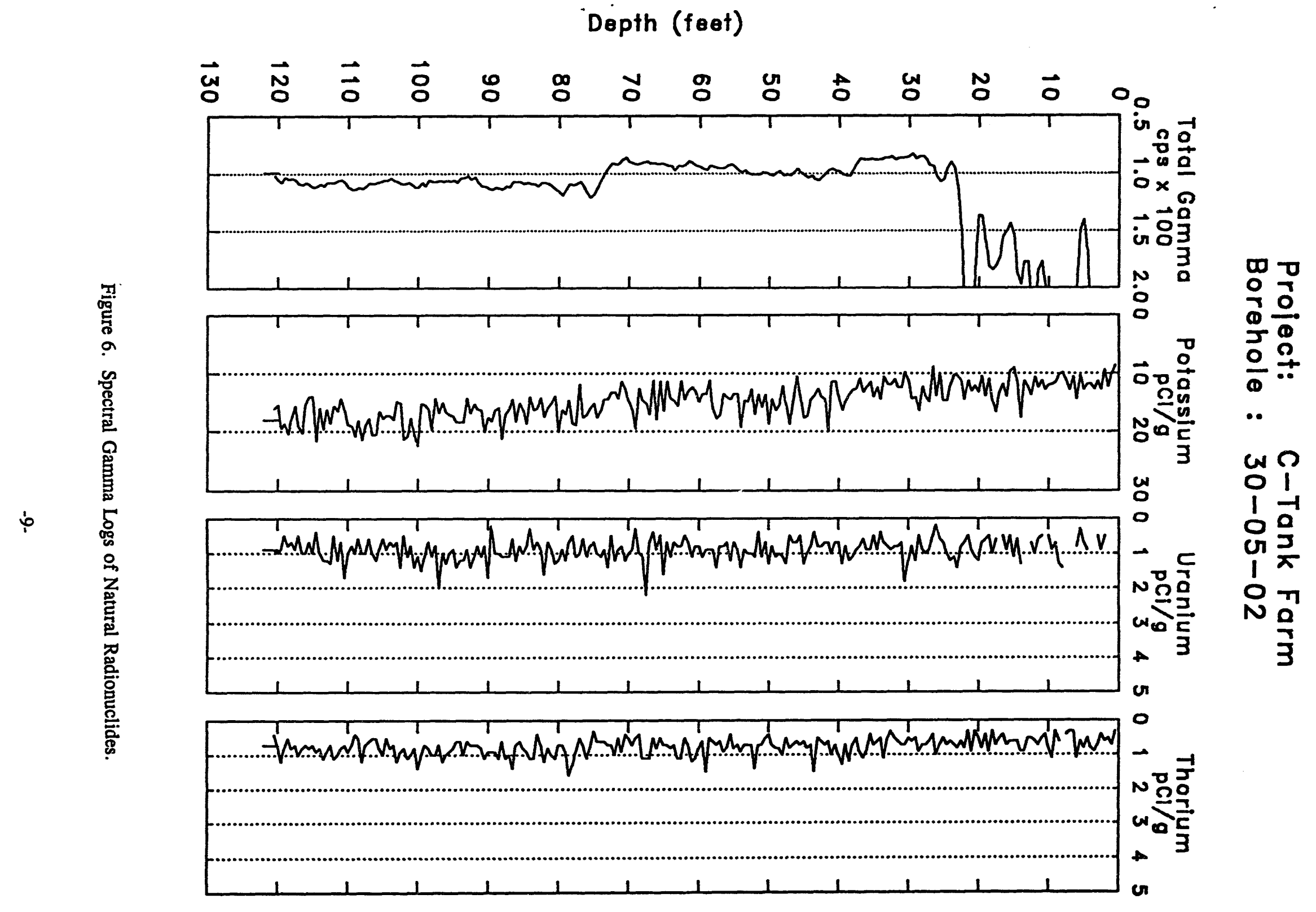


cesium three-dimensional plot is shown in Figure 7. The program allowed rotating the structure and viewing the radionuclide distribution from different angles. This was helpful in identifying the contamination sources.

However, this type of visualization can be misleading because the program only correlates between the boreholes that were logged with the spectral gamma system. Some of the cesium contamination may have originated from tanks adjacent to C-105 and C-106 and because cesium data are not available from these adjacent boreholes, those correlations are not shown in the plot.

The gross gamma log data were also put into a three-dimensional visualization plot to help identify contamination sources and correlate with the cesium concentration data.

\section{Assessment of gross gamma logs}

Review of the composite log plots from the 15 logged boreholes revealed a marked difference between the total gamma logs and the gross gamma logs. This was investigated further by plotting both data against the in situ ${ }^{137} \mathrm{Cs}$ concentration (Figure 8).

Note that the iotal gamma data produces a good correlation line. Data points falling to the right of the correlation line are the result of compton downscatter, photoelectric phenomenon, and higher concentrations of other radionuclides. The slope of the correlation line can be considered to be a total gamma-to- ${ }^{137} \mathrm{Cs}$, field calibration curve.

The gross gamma data did not correlate as well. There was considerably more spread and the count rates were much lower. The field calibration curve is not as well defined. However, the data show that the calibration curve is much steeper than the curve for the total gamma, indicating that the gross gamma system has a much lower sensitivity. Also evident is that very large scatter in the data below about $15 \mathrm{pCi} / \mathrm{g}(50 \mathrm{c} / \mathrm{s})$. This can be considered to be the low-level detection sensitivity of the gross gamma logging system, which is the limit of the historical record.

\section{Contamination sources}

The cesium contamination plots and threedimensional visualizations were reviewed along with the gross gamina visualizations to determine the sources of the contamination.

Cesium-137 proved to be a good radionuclide to assay for determining the sources because it was abundant in all of the boreholes, had a moderate migration tendency, was present in all of the tanks, and has not decayed away appreciably over the last 50 years.

The data showed the greatest source of cesium came from the region between tanks C-104 and C-105 (see Figures 3 and 7). This is a region where a pipeline connecting these two tanks is known to have leaked. The pipeline is about $15 \mathrm{ft}$ deep, which is well above the current liquid levels in both tanks.

The other large source of contamination is from extensive surface contamination that resulted from surface pipeline spills, air-borne releases, or a combination of the two. Figure 9 shows a threedimensional plot of the gross gamma data with a view of $\mathrm{C}$ tank farm surface activity. Clearly this was a major source of the unsaturated zone contamination.

Smaller quantities of contamination may have originated from adjacent tanks including tanks C-101, C-103, and C-109. Unfortunately, because the boreholes around these tanks were not logged with the spectral gamma system, these sources are postulated based on the gross gimma data. Future spectral gamma logging in boreholes around adjacent tanks will help to confirm these sources.

None of the zones of ${ }^{60} \mathrm{Co}$ contamination were detected with the gross gamma logs. This radionuclide has a lower sorption factor than cesium and tends to migrate further than cesium. Because ${ }^{80} \mathrm{Co}$ has a relatively short half life (5.27 years), only low concentrations were found in the unsaturated zone. It was not possible to identify the sources of cobalt.

Contamination stability and C-105. C-106 leak assessment

Virtually all of the zones of higher cesium concentration were present when the boreholes were first logged with the gross gamma system in the late 1970 's. The gross gamma log records do not show any large changes in the cesium concentration in the unsaturated zone. Relative to the precision of measurement of the cesium concentration with the gross gamma system, the contamination does not appear to be migrating, indicating a static situation. 


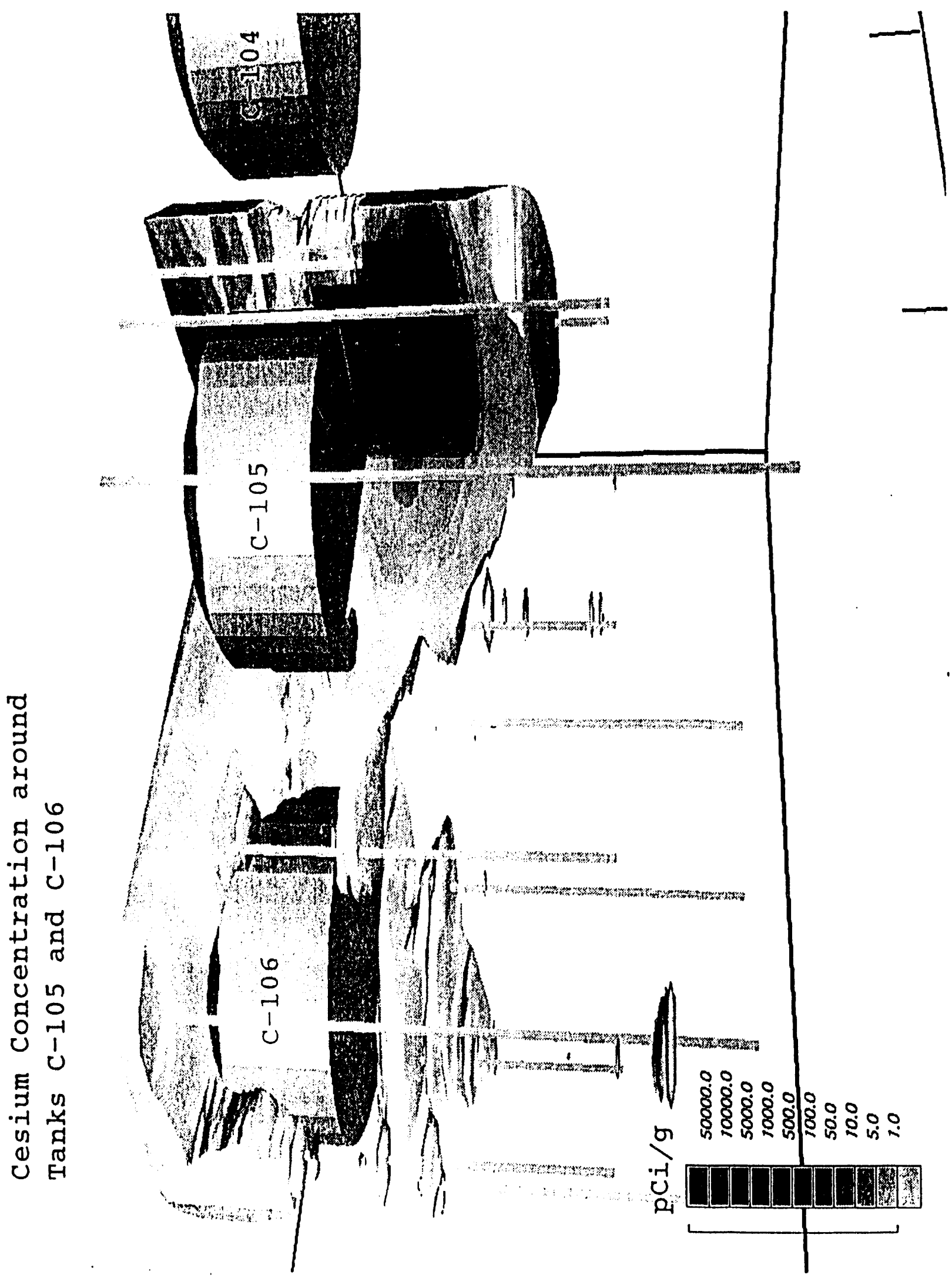

Figure 7. Three-Dimensional Visualization Plot of ${ }^{137} \mathrm{Cs}$ Distribution. 


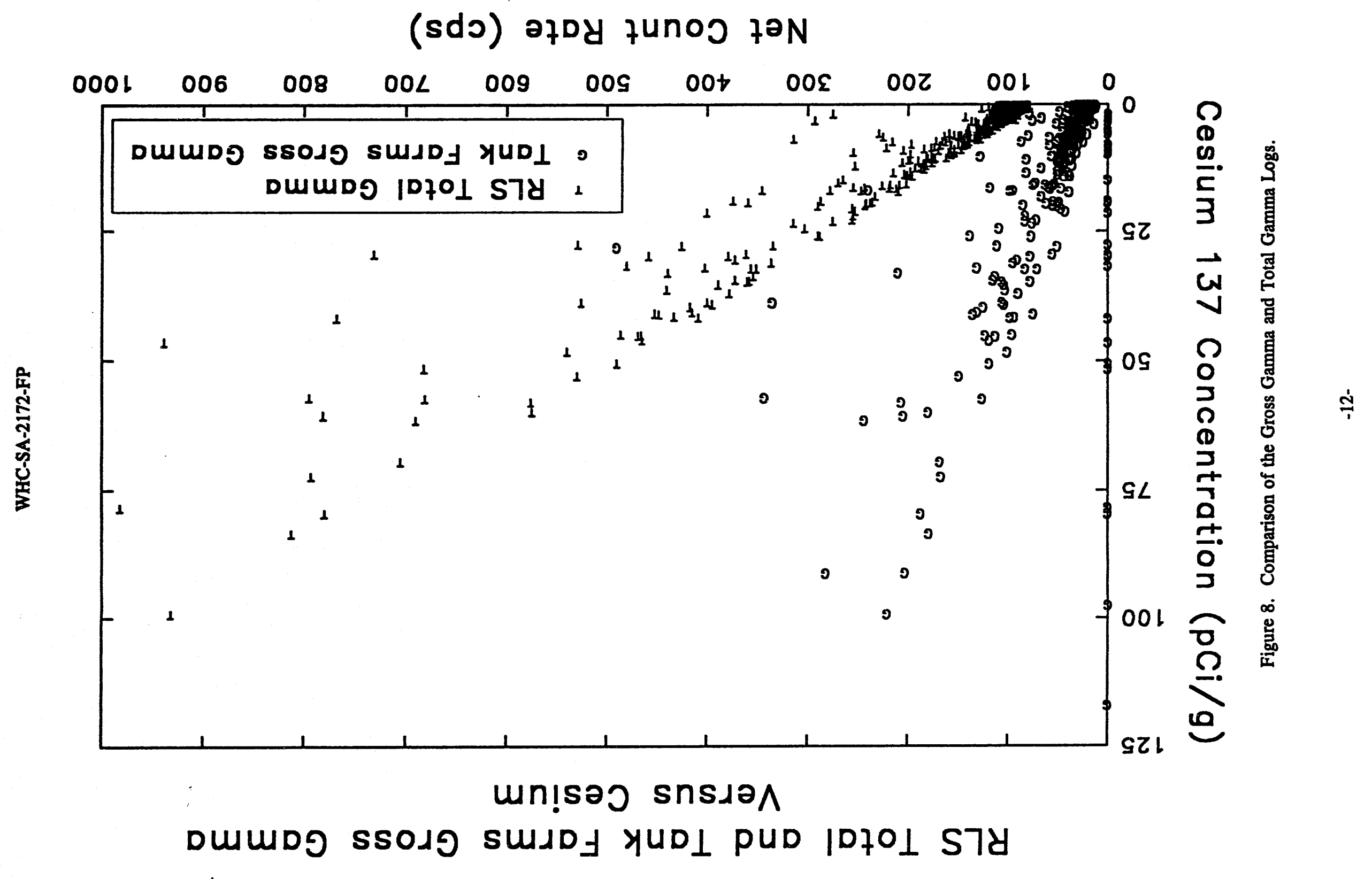




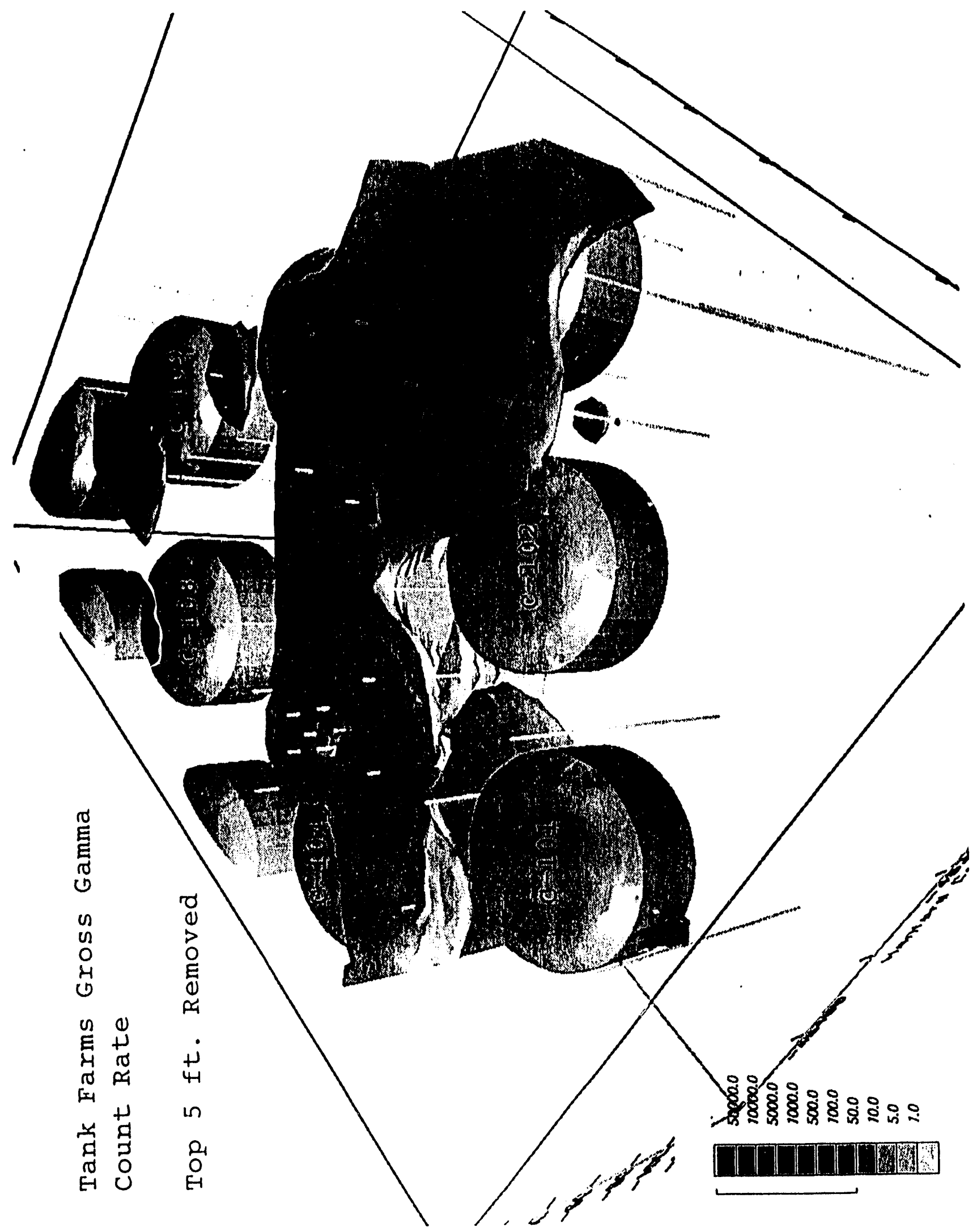

Figure 9. Three-Dimensional Visualization of Gross Gamma Data Showing Surface Contamination. 
Lower concentration zones (less than about $15 \mathrm{pCi} / \mathrm{g}$ ) were not detected with the gross gamma system, so nothing can be concluded about the stability of these zones. These zones of low cesium concentration may have resulted from a leak from one of the tanks, but at this point it is impossible to be certain.

Based on a comparison of the cesium concentration to the gross gamma baseline, there was no direct evidence of a leak from either tank C-105 or C-106. The spectral gamma logs from the boreholes around these tanks now constitutes a new baseline from which to compare future spectral log data.

Future spectral gamma logging in the boreholes around the adjacent tanks in $\mathrm{C}$ tank farm will provide a more complete understanding of the radionuclide distribution and more clearly identify all of the contamination sources.

Recommendations were made to improve the gross gamma logging program by increasing the efficiency of the detector, calibrating the system to an in situ radioelement concentration, and improving the spatial resolution.

\section{CONCLUSIONS}

A new generation of passive gamma-ray logging methods has been introduced at Hanford Site high- level nuclear waste tanks. This first logging enterprise proved to be of significant value in identifying the contamination and demonstrating what is possible with modern equipment and analysis methods.

Intrinsic germanium spectral gamma-ray logging methods will be used in the future for characterizing existing contamination, identifying leaks from tanks, and monitoring that contamination.

\section{REFERENCES}

Brodeur, J. R., C. J. Koizumi, W. H. Ulbricht, and K. R. Price, 1991, "Calibration of a High-Resolution Passive Gamma-Ray Logging System for Nuclear waste Assessment, " in Proceedings of the 4th International MGLS/KEGS Symposium on Borehole Geophysics for Minerals, Geotechnical and Groundwater Applications; Toronto, 18-22, August 1991.

Koirsmi, C. J., J. R. Brodeur, R. K. Price, J. E. Meisner, and D. C. Stromswold, 1994, "HighResolution Gamma-Ray Spectroscopy Logging for Contamination Assessment, " to be published in Nuclear Geophysics. 
